\title{
Larvae of the pycnogonids Ammothea striata (Möbius, 1902) and Ammothea carolinensis Leach, 1814 described from archived specimens
}

\begin{abstract}
John A. Fornshell
National Museum of Natural History, Department of invertebrate Zoology, Smithsonian Institution, 4210 Silver Hill Road, Suitland, Maryland 20746, USA. E-mail: johnfornshell@hotmail.com

ABSTRACT: The lecithotrophic larva of two species in the family Ammotheidae Dohrn, 1881, Ammothea striata (Möbius, 1902) and Ammothea carolinensis Leach, 1814 are described from archived specimens. Larvae were recovered from the ovigers of adult male specimens. The three post-embryonic instars from second to fourth of $A$. carolinensis were present on the archived specimens. Two stages of $A$. striata larvae were present, presumably the second and third post-embryonic instars. Larvae were studied using a scanning electron microscope. The length of larvae and measurements of the cheliphores, larval appendages II and III are reported. The development of the first two walking legs is reported for the second through the fourth instars of $A$. carolinensis and second and third instars of $A$. striata. Larval appendages III show varying patterns of reduction during the post-embryonic development of the members of the genus Ammothea. The patterns present in A. striata and A. carolinensis are compared to those found in five other members of the genus Ammothea, A. gigantea Gordon, 1932, A. glacialis (Hodgson, 1907), A. longispina Gordon, 1932, A. bicorniculata Stiboy-Risch, 1992, and A. spinosa (Hodgson, 1907). Two other species from the family Ammotheidae, Tanystylum bealensis and T. orbiculare Wilson, 1878, are also compared.

How to cite this article: Fornshell J.A. 2014. Larvae of the pycnogonids Ammothea striata (Möbius, 1902) and Ammothea carolinensis Leach, 1814 described from archived specimens // Invert. Zool. Vol.11. No.2. P.325-334.
\end{abstract}

KEY WORDS: Pycnogonida, larvae, protonymphon, morphology, SEM.

\section{Личинки пикногонид Ammothea striata (Möbius, 1902) and Ammothea carolinensis Leach, 1814, описанные по коллекционному материалу}

\author{
Джон А. Форншелл
}

National Museum of Natural History, Department of invertebrate Zoology, Smithsonian Institution, 4210 Silver Hill Road, Suitland, Maryland 20746, USA. E-mail: johnfornshell@hotmail.com

PЕЗЮМЕ: Описаны лецитотрофные личинки двух видов из семейства Ammotheidae Dohrn, 1881: Ammothea striata (Möbius, 1902) и Ammothea carolinensis Leach, 1814 на основе материала из музейной коллекции. Личинки были сняты с яйценосных ножек самцов. На особях из коллекционного материала найдено три (вторая - четвёртая) личиночные стадии A. carolinensis. Для A. striata имелось две личиночные стадии, 
предположительно вторая и третья. Личинок изучали с помощью сканирующего электронного микроскопа. Приведены длина тела личинок и измерения хелифор, а также личиночных ножек II и III пар. Развитие двух передних пар ходильных ног описано до четвёртой стадии у A. carolinensis и у второй и третьей стадий A. striata. Процесс редукции личиночных конечностей III пары в ходе личиночного развития у представителей рода Ammothea проходит по-разному. Проведено сравнение вариантов, наблюдаемых у A. striata и A. carolinensis, с описанными для пяти других представителей рода Ammothea: A. gigantea Gordon, 1932, A. glacialis (Hodgson, 1907), A. longispina Gordon, 1932, A. bicorniculata Stiboy-Risch, 1992 и A. spinosa (Hodgson, 1907). В сравнительный анализ включены ещё два вида из семейства Ammotheidae: Tanystylum bealensis и T. orbiculare Wilson, 1878.

Как цитировать эту статью: Fornshell J.A. 2014. Larvae of the pycnogonids Ammothea striata (Mцbius, 1902) and Ammothea carolinensis Leach, 1814 described from archived specimens // Invert. Zool. Vol.11. No.2. P.325-334.

КЛЮЧЕВЫЕ СЛОВА: Pycnogonida, личинки, протонимфон, морфология, СЭМ.

\section{Introduction}

The Pycnogonida is a class in the phylum Arthropoda which are usually considered the sister group of the remaining Chelicerata or less often the sister group of the remaining members of the phylum Arthropoda (Dunlop, 2005; Dunlop, Arango, 2005; Bamber, 2007). The first post-embryonic stage of development is a protonymphon larva which is characterized by an unsegmented body with a tripartite mouth at the end of a proboscis and the anterior three pairs of limbs developed. The first pair of larval appendages is the chelifores and remains this way throughout development. The second and third pairs of appendages present in the protonymphon larva, appendages II and III are larval appendages for walking and (rarely) swimming (Hoek, 1881; Morgan, 1891; Hodgson, 1907). The earliest account of the larval stages of the Pycnogonida appears in the nineteenth century, beginning with Phoxichilidium femoratum (Rathke, 1799) in 1854 (Bain, 2003). The name protonymphon for pycnogonid larvae was proposed by Hoek (1881). The first complete description of the post-embryonic stages of development from hatching to adult form of Phoxichilidium femoratum was published by Adlerz (1888). Morgan (1891) published a complete description of the post-embryonic development from hatching to adult of Tanystylum orbiculare Wilson, 1878. Among approximately thirteen hundred known species (Arango, Wheeler, 2007) larvae of about 70 species (about 5\%) have been described, and complete development from hatching to adult has been described for only a small number of species (Bogomolova, Malakhov, 2006). This paper describes in detail the second to fourth post-embryonic stages of two different species of Ammothea, A. carolinensis Leach, 1814 and A. striata (Möbius, 1902) and then compares these to similar stages in the five other species of Ammothea, A. gigantea Gordon, 1932, A. glacialis (Hodgson, 1907), A. longispina Gordon, 1932, A. bicorniculata Stiboy-Risch, 1992, A. spinosa (Hodgson, 1907) and Tanystylum bealensis (see: Gillespie, Bain, 2006) and T. orbiculare Wilson, 1878 (see: Morgan, 1891).

\section{Methods}

The source of the protonymphon larvae of Ammothea carolinensis (USNM 127244 and 127245) and A. striata (USNM 123115) for this study was archived specimens from the collections of the National Museum of Natural History, Smithsonian Institution identified by Dr. C. Allen Child. Larvae were recovered from the ovigers of adult male specimens. Three instars 
of $A$. carolinensis were present on the ovigerous appendages of the archived specimens. Four specimens each of the second and third instars and two specimens of the fourth instar were used in this study. A. striata post-larvae were present on an ovigerous male specimen as two stages, presumably the second and third instars. Four specimens of the second stage and two of the third stage were used in this study. Larvae were dehydrated in progressively more concentrated ethanol solutions and critical point dried and coated with gold alloy for the scanning electron micrographs using a Philips XL30 ESEM LaB6 Electron Microscope. The length of each larva was measured from the electron micrographs from the base of the cheliphores to the posterior end of the animal.

The following labels are used in the electron micrographs: $\mathrm{AB}$ - àbdomen; $\mathrm{CH}$ - ñheliphores; CL — terminal claw with two auxiliary claws present; PC - proctodeum; PR - proboscis; SI - sensilla; SP — spines; TM tripartite mouth; II — second larval appendages; III — third larval appendages; IV — walking leg one; V — walking leg two; VI — walking leg three; $1-\operatorname{coxa} 1 ; 2-\operatorname{coxa} 2 ; 3-\operatorname{coxa} 3 ; 4 /$ 5 - femur-tibia I; 6 - tibia II; 7 - tarsus; 8 propodus.

\section{Results}

The second through fourth instars of $A$. carolinensis and the second and third instars of A. striata are described in this section. A true protonymphon larva was not found in archived material of either of the species studied here. Prior to hatching from the egg, the larval appendages are typically compressed to the body of the larva. These three larval appendages straighten and become smoothed out after hatching. At the first post-embryonic instar the three larval appendages are much more fully formed (Bogomolova, personnel communication). The three larval appendages in our specimens in the earliest observed stages are not compressed and wrinkled. The proboscis is longer than the chelifores. Cano and López-González, 2013 describe the second instar of $A$. carolinensis as having a proboscis which is longer than the cheliphores as seen in our specimens (Fig. 1A). In the earliest stages in our specimens, the larva appears to be molting its first exoskeleton and emerging as the second instar.

\section{Larvae of Ammothea carolinensis}

The second instar of $A$. carolinensis (Fig. $1 \mathrm{~A}-\mathrm{C}$ ) has a body which is oval in shape when viewed from the dorsal aspect. The length of the body is $800 \mu \mathrm{m}$. The proboscis which is oriented ventrally at the anterior end of the body is $350 \mu \mathrm{m}$ in length. The mouth is tripartite and Y-shaped. The cheliphores are 330 $\mathrm{mm}$ long and lack teeth and an attachment gland spine. The scape of the cheliphore is 160 $\mu \mathrm{m}$ long $\times 200 \mu \mathrm{m}$ wide and has two short curved spines, one on the dorsal side and one on the lateral side. The $120 \mu \mathrm{m}$ long second segment, palm, of the cheliphore has a short curved spine just below the base of the third segment, movable finger. The molting of the protonymphon larva into the first post-larval stage is shown in Fig. 1A. The third segment of the cheliphore is $130 \mu \mathrm{m}$ long. Larval appendages II are three-segmented with a lateral spine on the first segment and a medial spine on the second segment (Fig. 1C). These spines are 20 $\mathrm{mm}$ long. The third segment is subchelate. The lengths of the three segments proximal to distal are $67 \mu \mathrm{m}, 74 \mu \mathrm{m}$ and $50 \mu \mathrm{m}$. Larval appendages III are three-segmented (Fig. 1C). The proximal segment is $36 \mu \mathrm{m}$ long with a medial spine. The second segment is $57 \mu \mathrm{m}$ long with one medial spine. The third subchelate segment is $21 \mu \mathrm{m}$ long. The buds of the first walking legs have three articles or pseudosegments, which are not delineated by arthrodial membranes. There is a ventral-lateral spine on the terminal article of each bud (Fig. 1B). On the ventral side of the body there are two depressions corresponding to the developing ganglia of the ventral nerve cords which are posterior to the three larval appendages and medial to the base of the buds of the first walking legs (Fig. 1B). Neither eyes nor a tubercle with eyes were not observed in any of the electron micrographs. 

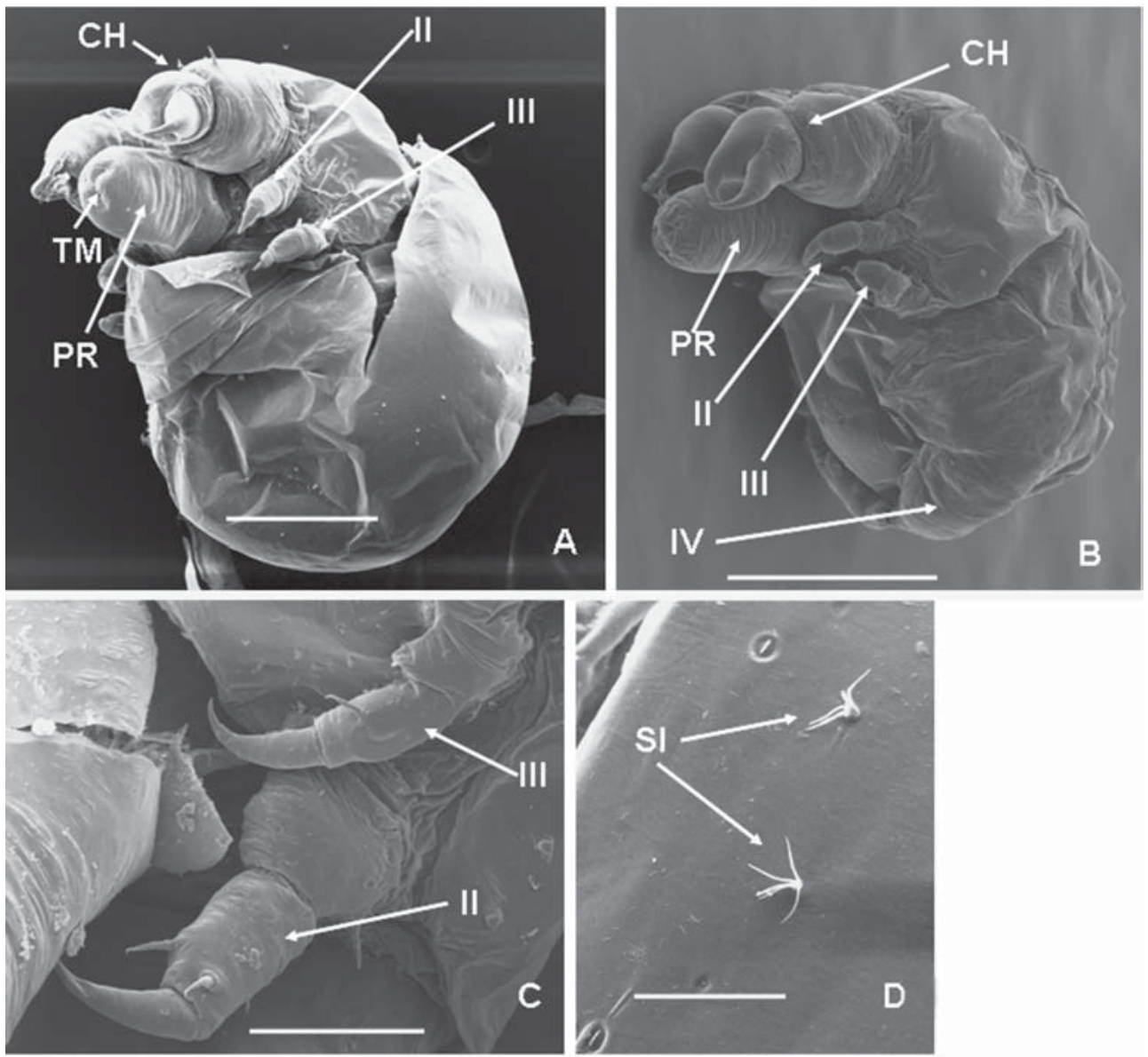

Fig. 1. Early larval instars of Ammothea carolinensis.

A - molting of the protonymphon larva into the second instar; B - lateral view of the second instar; C - larval appendages II and III of the second instar; D - sensilla on the scape of the cheliphore of the third instar. Scale bars: A, $\mathrm{B}-200 \mu \mathrm{m} ; \mathrm{C}-100 \mu \mathrm{m} ; \mathrm{D}-20 \mu \mathrm{m}$.

Рис. 1. Ранние личиночные стадии Ammothea carolinensis.

А - линька протонимфона во 2-ю личиночную стадию; В - 2-я личиночная стадия, вид сбоку; С - 2-я личиночная стадия: личиночные конечности II и III пар; D - 3-я личиночная стадия: сенсиллы на 1-м членике хелифоры. Масштаб: А, В - 200 мкм; C - 100 мкм; D - 20 мкм.

The third instar of $A$. carolinensis (Fig. 2A, B) has a relatively large proboscis with a tripartite mouth. The cheliphores have two short curved spines on the first segment and one on the second segment as in the second instar. No teeth are present on the cheliphores. There are numerous four filament sensilla present on the first two segments (Fig. 1D). Larval appendages II are three-segmented with one spine on the first segment and one on the second segment. The third segment is subchelate. Larval ap- pendages III are three-segmented with one spine on the proximal segment and a relatively thin spine on the second segment. The first walking leg has seven segments, coxa I; coxa II; coxa III, femur-tibia I, tibia II, tarsus, propodus and terminal claw, with two auxiliary claws present. The pattern of the spines on the first walking leg in the second instar could not be determined. The underived buds of the second walking leg are present with a spine on the terminal articles. 


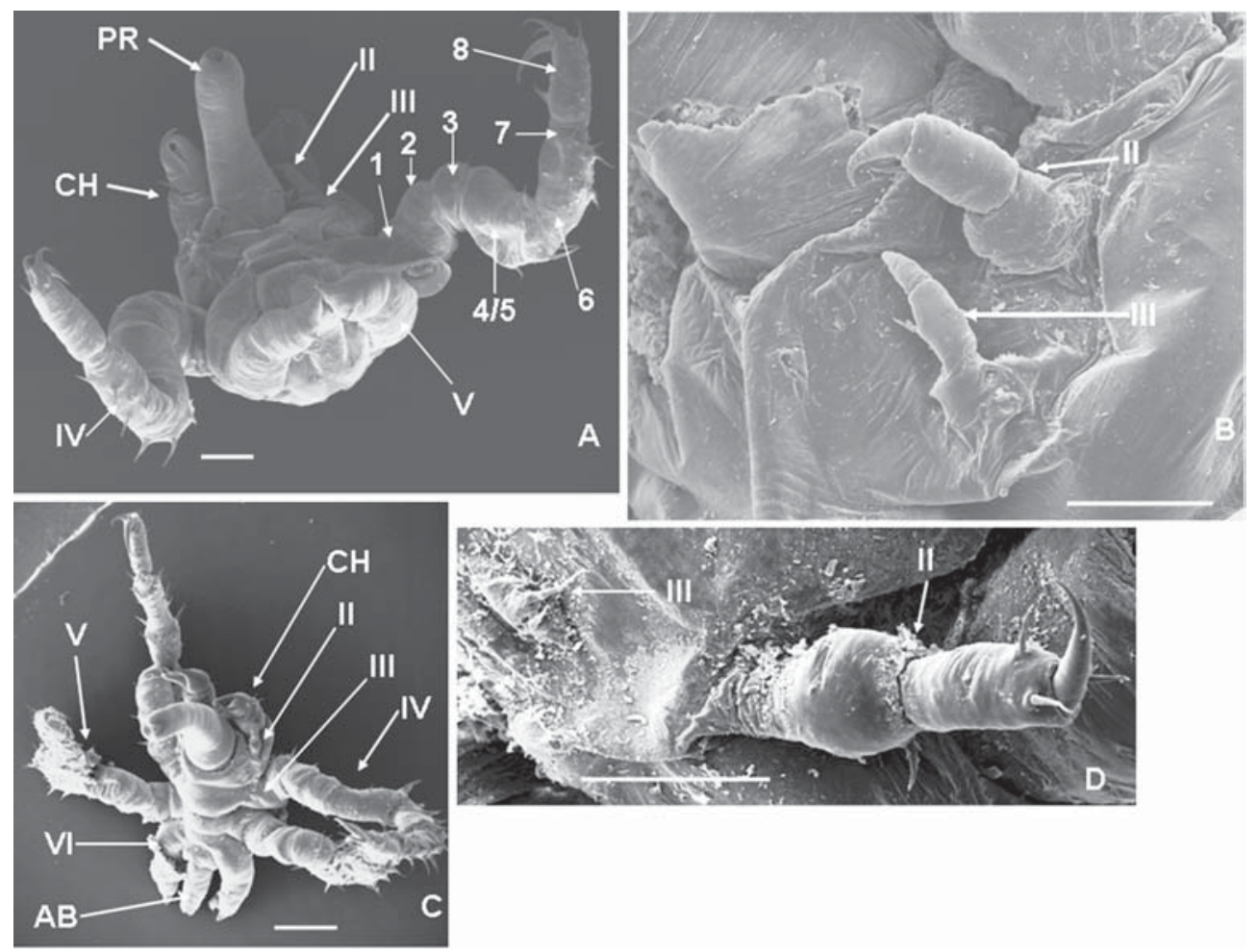

Fig. 2. Larvae of Ammothea carolinensis.

A - posterior ventral view of the third instar; B - larval appendages II and III of the third instar; C - fourth instar; D - larval appendages II and III of the fourth instar. Scale bars: A, C $-500 \mu \mathrm{m}$; B, D $-100 \mu \mathrm{m}$.

Рис. 2. Личинки Ammothea carolinensis.

A - 3-я личиночная стадия, постеро-вентральный вид; В - 3-я личиночная стадия: личиночные конечности II и III пар; C - 4-я личиночная стадия; D - 4-я личиночная стадия: личиночные конечности II и III пар. Масштаб: А, C -500 мкм; B, D - 100 мкм.

The fourth instar of $A$. carolinensis (Fig. 2C) shows no morphological changes in either the proboscis or the chelifores. The first walking leg is eight-segmented, coxa I, coxa II, coxa III, femur, tibia I, tibia II, tarsus, propodus, and terminal claw, with two auxiliary claws present. The second walking leg is seven-segmented with the same segmentation as the first walking leg in the second instar larva. The pattern of spines on the walking legs in the fourth instar could not be determined. The third walking leg buds are also present. Larval appendages II have three distal spines on the second segment. The larval appendages III are reduced to a single large two- segmented spine with a small adjacent spine (Fig. 2D). A primordium of the proctodeum is present on the posterior of the abdomen.

\section{Larvae of Ammothea striata}

The protonymphon of $A$. striata molting into the second instar is shown in Fig. 3A.

The second instar of $A$. striata (Fig. 3B, 3C and 3D) has an oval body $520 \mu \mathrm{m}$ long $\times 466 \mu \mathrm{m}$ wide. The buds of the first walking legs and proboscis are like those of $A$. carolinensis at the same stage of development. The cheliphores lack an attachment gland spine and teeth. The scape which is $200 \mu \mathrm{m}$ long and wide has two short curved spines (Figs. 3A, B, D). The second segment, palm, of the cheliphore is $310 \mu \mathrm{m}$ long $\times 200 \mu \mathrm{m}$ wide, and has one short curved spine at the base of the third segment, movable finger. The, movable, third segment is $155 \mu \mathrm{m}$ long and $100 \mu \mathrm{m}$ wide at its base. There are many four branched sensilla on the segments of 

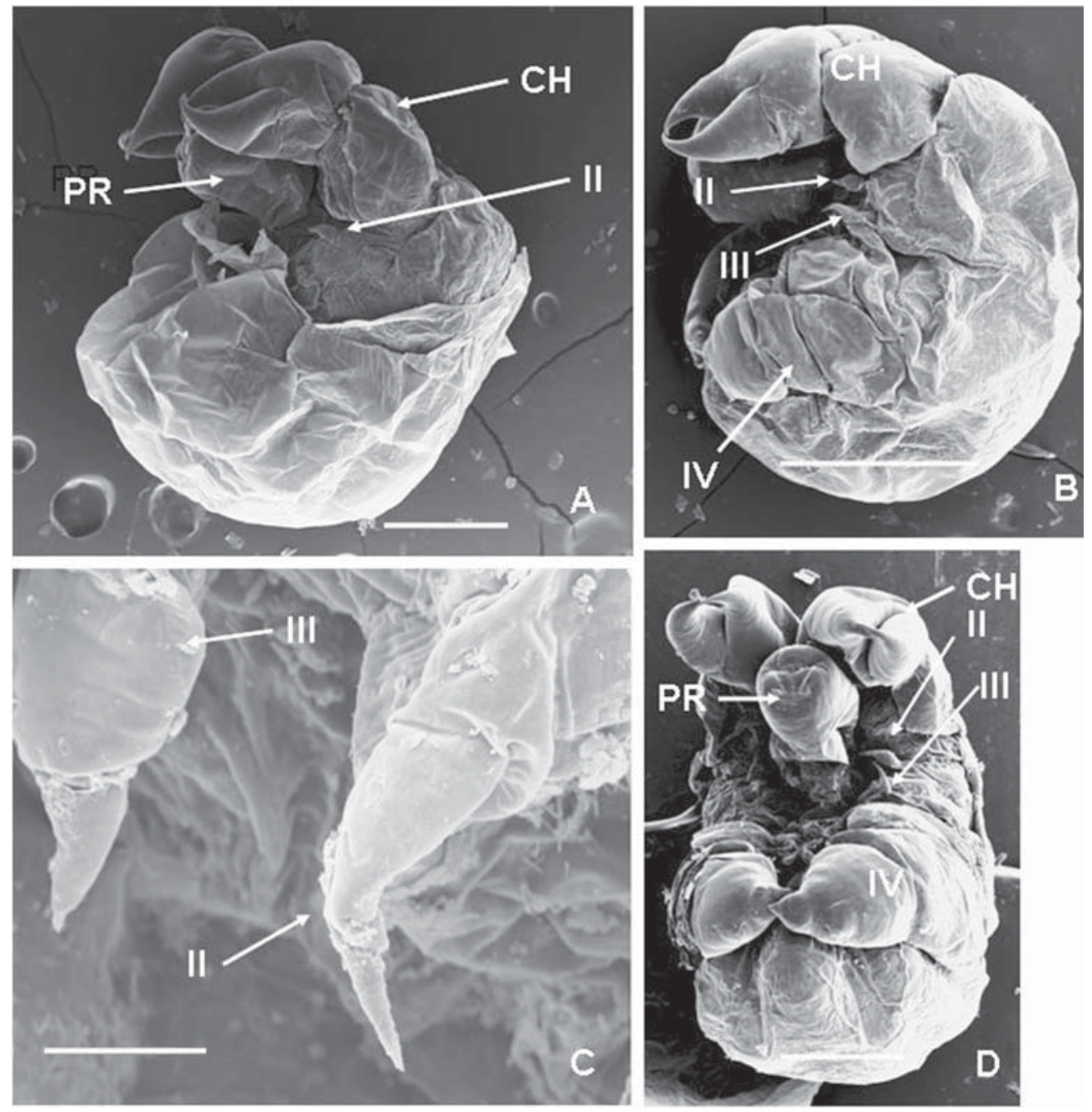

Fig. 3. Early larval instars of Ammothea striata.

A - molting of the protonymphon larva into the second instar; B - lateral view of the second instar; C - larval appendages II and III of the second instar; D - ventral view of the second instar. Scale bars: A, B, D - $200 \mu \mathrm{m}$; C $20 \mu \mathrm{m}$.

Fig. 3. Ранние личиночные стадии Ammothea striata.

А - линька протонимфона во вторую личиночную стадию; В - 2-я личиночная стадия, вид сбоку; С -2 -я личиночная стадия: личиночные конечности II и III пар; D - 2-я личиночная стадия, в вентральной стороны. Масштаб: А, B, D - 200 мкм; C - 20 мкм.

the cheliphores. The larval appendages II are two-segmented at this stage. The first segment is $46 \mu \mathrm{m}$ long and $20 \mu \mathrm{m}$ wide at its base (Fig. 3C). The subchelate second segment is $11 \mu \mathrm{m}$ long and $6 \mu \mathrm{m}$ wide at its base. Neither segment has a spine. Larval appendage III is also two-segmented, the first segment is $46 \mu \mathrm{m}$ long and the second subchelate segment is $13 \mu \mathrm{m}$ long.
In the third instar of $A$. striata the first walking legs are six-segmented, consisting of the coxa I, coxa II, coxa III, femur-tibia I, tibia II, tarsus-propodus and terminal claw, with two auxiliary claws present. The buds of the second walking legs are present with a spine on the distal most, third, article (Fig. 4A). The primordium of an anus or proctodeum is present on the 


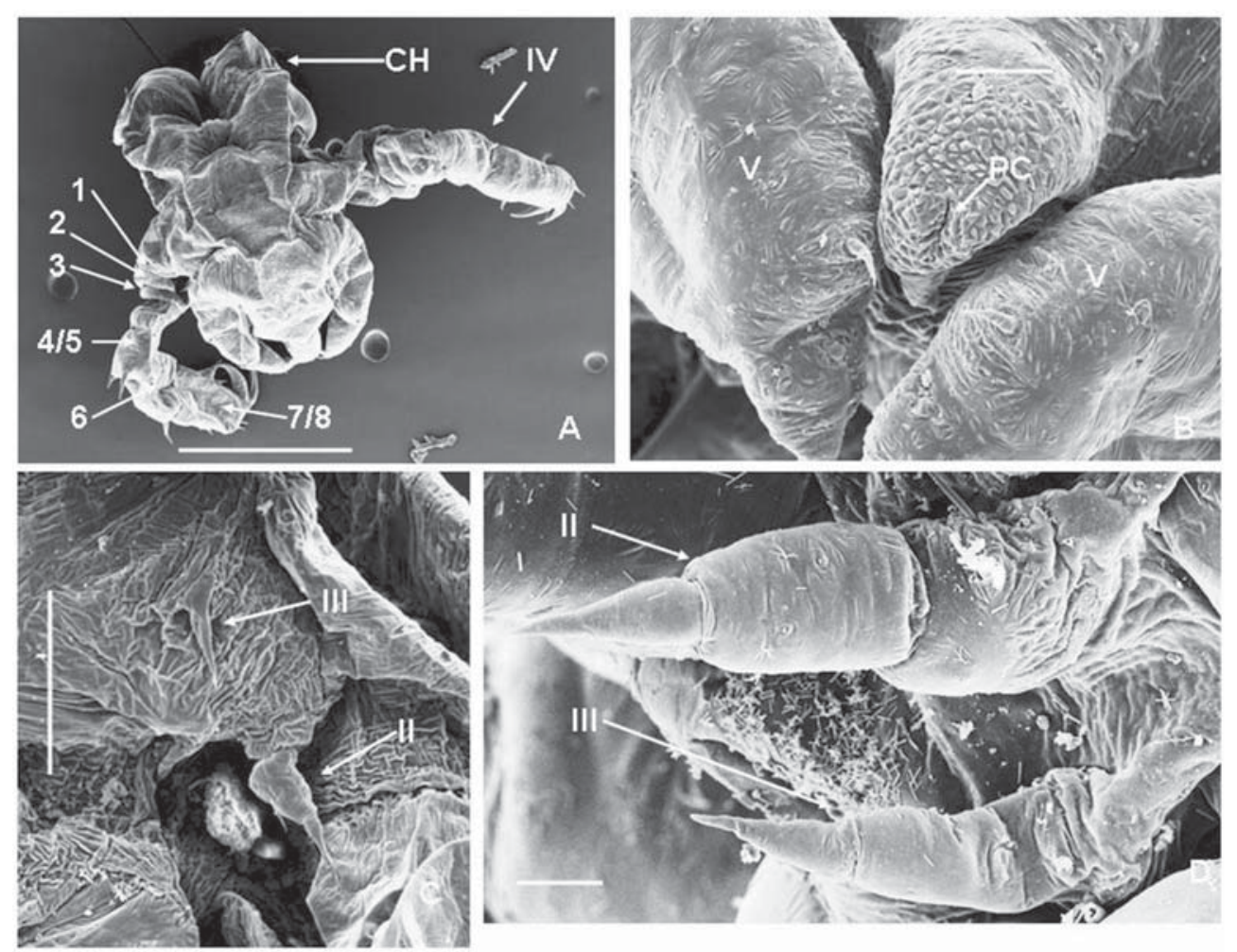

Fig. 4. Larvae of Ammothea striata and Ammothea glacialis.

A - third instar of A. striata; B - abdomen of the third instar of A. striata; C - larval appendages II and III of the third instar of A. striata; D - larval appendages II and III of the third instar of A. glacialis. Scale bars: A $-500 \mu \mathrm{m}$; B $50 \mu \mathrm{m} ; \mathrm{C}-100 \mu \mathrm{m} ; \mathrm{D}-20 \mu \mathrm{m}$.

Fig. 4. Личинки Ammothea striata и Ammothea glacialis.

А - A. striata, 3-я личиночная стадия; В - A. striata, 3-я личиночная стадия: абдомен; С - A. striata, 3-я личиночная стадия: личиночные конечности II и III пар; D - A. glacialis, 3-я личиночная стадия: личиночные конечности II и III пар. Масштаб: А - 500 мкм; В - 50 мкм; C - 100 мкм; D - 20 мкм.

abdomen (Fig. 4B). The pattern of the spines on the first walking leg in the second instar could not be determined. The cheliphores and proboscis are morphologically unchanged. Two-segmented larval appendages II are present. The first segment is $80 \mu \mathrm{m}$ long and the second subchelate segment $20 \mu \mathrm{m}$ long (Fig. 4C). The larval appendages III are present as a very short proximal segment each with a single spine and the second segment represented as an $80 \mu \mathrm{m}$ long spine.

\section{Discussion}

In A. glacialis larval appendages III are three-segmented in the second (Fig. 4D), third
(Fig. 5A) and fourth instars (Fig. 5B) (see also: Cano, López-González, 2009; Ferrari et al., 2011). In A. gigantea the larval appendage is three-segmented in the second instar (Fig. 5B; Fornshell, Ferrari, 2012) and reduced to a large simple spine in the third instar (Fig. 5C). In $A$. carolinensis the appendages III are threesegmented in the second instar, three-segmented in the third instar and two-segmented in the fourth instar (Figs. 1C, 2B, 2D). The larval appendage III in this species is much smaller than the larval appendage II in the second instar, unlike $A$. glacialis and $A$. carolinensis. In $A$. striata the larval appendages III are twosegmented in the second post-hatching stage. In the third instar, they are reduced to in size 

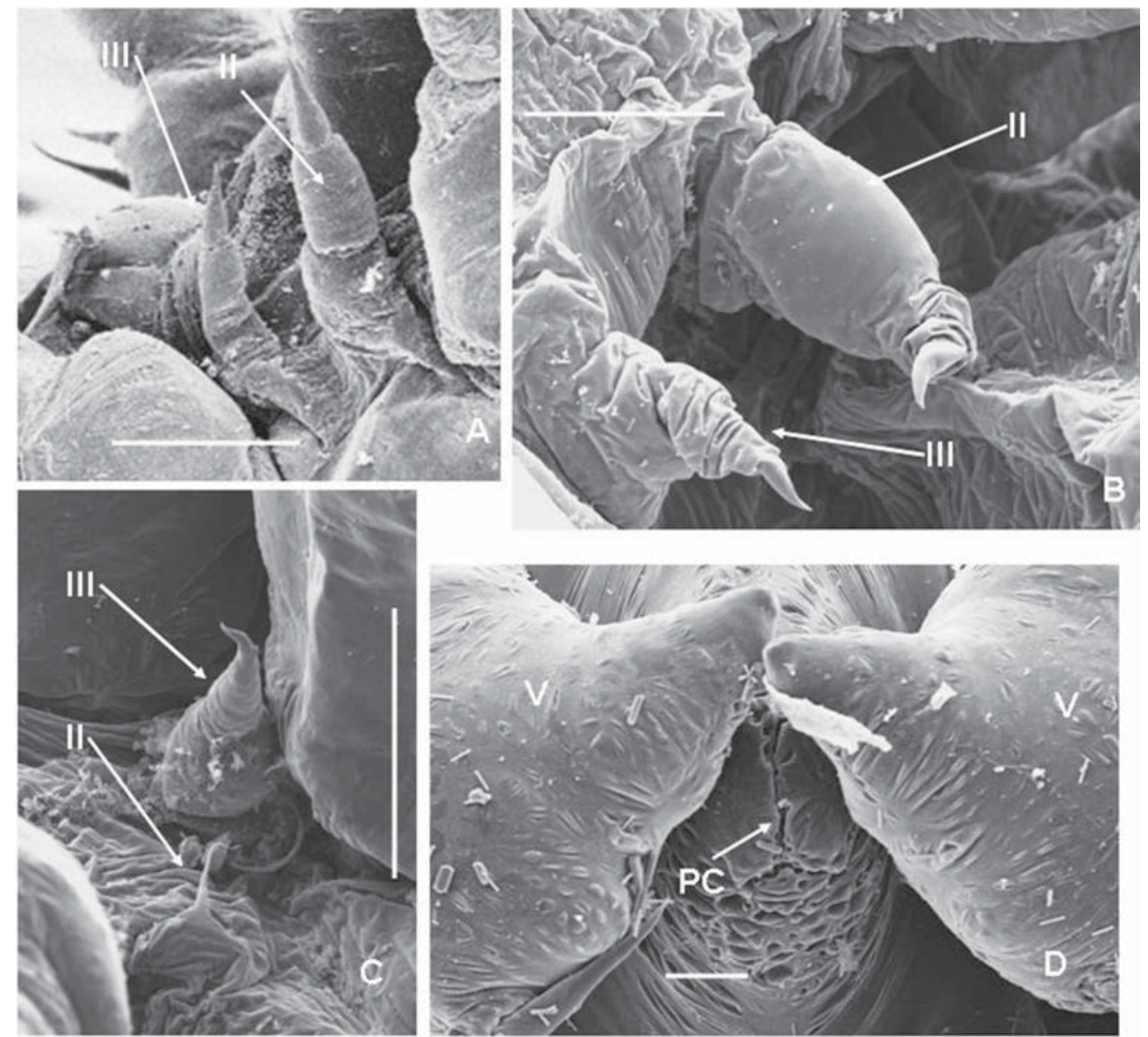

Fig. 5. Larvae of Ammothea glacialis and A. gigantea.

A - larval appendages II and III of the fourth instar of A. glacialis; B - larval appendages II and III of second instar of A. gigantea; $\mathrm{C}$ - larval appendage II and III of the third instar of A. gigantea; D - abdomen and proctodeum of the third instar of A. glacialis. Scale bars: A, C $-100 \mu \mathrm{m} ; \mathrm{B}-50 \mu \mathrm{m}$; D $-20 \mu \mathrm{m}$.

Fig. 5. Личинки Ammothea glacialis и A. gigantea.

A - A. glacialis, 4-я личиночная стадия: личиночные конечности II и III пар; В - A. gigantea, 2-я личиночная стадия: личиночные конечности II и III пар; C - A. gigantea, 3-я личиночная стадия: личиночные конечности II и III пар; D - A. glacialis, 3-я личиночная стадия: абдомен и проктодеум. Масштаб: А, C - 100 мкм; В - 50 мкм; $\mathrm{D}-20$ мкм.

compared to the second instar (Figs. 3C, 4D). In $A$. longispina larval appendage III is twosegmented in the three post-embryonic instars (Cano, López-González, 2009). In A. spinosa and $A$. bicorniculata larval appendage III is three-segmented in the three post-embryonic instars (Cano, López-González, 2009). Larval appendage III is three-segmented in Tanystylum bealensis (after Gillespie, Bain, 2006; note: Tanystylum bealensis does not appear to be a valid species). Morgan (1891) described larval appendage III of $T$. orbiculare as threesegmented in the first three post embryonic instars. The observations of the reduction of the larval ovigerous appendage are summarized in Table 1. The larval appendage II are three-segmented in all observed larval stages of A. glacialis, A. gigantea, and A. carolinensis, A. bicorniculata, T. bealensis, T. orbiculare and $A$. spinosa and two-segmented in $A$. striata and $A$. longispina (Cano, López-González, 2009; Morgan, 1891). 
Table 1. The pattern of reduction in the segmentation of the larval appendages III in the first three postembryonic instars of Ammothea and Tanystylum. Data for A. longispina, A. bicorniculata and A. spinosa are from Cano and López-González (2013). Data for T. bealensis are from Gillespie and Bain (2006).

Data for T. orbiculare are from Morgan (1891).

Таблица 1. Варианты редукции личиночных конечностей III у трёх первых постэмбриональных стадий Ammothea и Tanystylum. Данные для A. longispina, A. bicorniculata и A. spinosa приведены по: Cano, Lypez-Gonzбlez (2013). Данные для T. bealensis взяты из работы Gillespie, Bain (2006). Данные для T. orbiculare из работы Morgan (1891).

\begin{tabular}{|l|c|c|c|}
\hline Species & Second Instar & Third Instar & Fourth Instar \\
\hline A. glacialis & 3 segments & 3 segments & 3 segments \\
\hline A. carolinensis & 3 segments & 3 segments & 2 segments \\
\hline A. striata & 2 segments & 2 segments & no data \\
\hline A. gigantea & 3 segments & single spine & no data \\
\hline A. longispina & 2 segments & 2 segments & 2 segments \\
\hline A. bicorniculata & 3 segments & 3 segments & 3 segments \\
\hline A. spinosa & 3 segments & 3 segments & 3 segments \\
\hline T. bealensis & 3 segments & 3 segments & 3 segments \\
\hline T. orbiculare & 3 segments & 3 segments & 3 segments \\
\hline
\end{tabular}

The morphology and spine patterns on the cheliphores are the same in all seven species of Ammothea larva described so far. One of the two spines observed on the scape of the cheliphore may be a reduced attachment gland spine. The attachment gland is not visible in the electron micrographs. Cano and López-González (2009) believed this organ to be lacking.

An anus or primordium of a proctodeum has been observed in the third instar of $A$. gigantea (Fornshell, Ferrari, 2012) and in A. striata in this study. It is also present in electron micrographs of the third instar of A. glacialis (Fig. $5 \mathrm{D})$. The presence of a primordium of a proctodeum in the third instar of three species of Ammothea is a significant variation. Observations of these species are needed to determine when the digestive tract of the larva is complete and functional.

The larval appendages II and III are much smaller than the cheliphores in A. gigantea, $A$. glacialis, A. longispina, A. bicorniculata, A. carolinensis A. spinosa and $A$. striata (Cano, López-González, 2009, 2013). Larval appendages II and III are approximately the same length as the cheliphores, though differing in form from the cheliphores in A. clausi (Cano, López-González, 2013).
The interpretation of the stages of development of members of the genus Ammothea used in this paper follows that of Cano and LópezGonzález, (2009, 2013), Ferrari et al. 2011 and Fornshell and Ferrari 2012. In their observations the buds of the first walking legs appear in the second instar, first post-protonymphon stage. The buds of the successive the second pair of walking legs appear in instar three and the buds of the third pair of walking legs appear in instar four. This is less than that reported for Taystylum balensis (Gillespie and Bain 2006) and for T. orbiculare are from Morgan (1891). Gillespie and Bain (2006) based their work on Taystylum balensis specimens cultured in the laboratory and Morgan (1891) had access to a local population of $T$. orbiculare. The use of archived specimens may result in missing of some short lived instars.

Cano and López-González (2009) described the larval development of Ammothea glacialis. They believed that a first stage of post-embryonic development to be the protonymphon larva, but did not find this stage in their specimens. Ferrari et al. (2011) proposed the first larval stage was a larva with one pair of developing walking legs and that there was no earlier stage within the egg of this species. This same larval 
developmental pattern was described for $\mathrm{Am}$ mothea gigantea (Fornshell, Ferrari, 2012). Cano and López-González (2013) describe a true protonymphon larva for $A$. carolinensis, $A$, longispina, A. bicorniculata, A. spinosa, A. minor and A. clausi. Based on the larva undergoing ecdysis in this paper (Fig. 1A, 3A) and Figure 5 in the paper by Fornshell and Ferrari (2012), it would appear that Ferrari et al. (2011) and Fornshell and Ferrari (2012) misinterpreted the sequence of larval development, and that a true protonymphon larva does occur in this genus.

\section{References}

Adlerz G. 1888. Bidrag till Pantopodermas morfologi och utvecklingshistoria // Bihang till Kongliga Svenska Vetenskaps-Akademiens handlingar. Bd.13. Afd.4. No.11. S.1-25.

Arango C.P., Wheeler W.C. 2007. Phylogeny of the sea spiders (Arthropoda, Pycnogonida) based on direct optimization of six loci and morphology// Cladistics. Vol.23. P.255-293.

Bain B.A. 2003. Larval types and a summary of postembryonic development within the Pycnogonida // Invertebrate Reproduction and Development. Vol.43. No.3. P.193 - 222.

Bamber R. N. 2007. A holistic re-interpretation of the phylogeny of the Pycnogonida Latreille, 1810 (Arthropoda) // Zootaxa. Vol.1668. P.295-312.

Bogomolova E.V., Malakhov V.V. 2006. [Lecithotrophic protonymphon is a special type of postembryonic development of sea spiders (Arthropoda, Pycnogoni- da)] // Doklady Akademii Nauk. Vol.409. No.4. P.328331 [in Russian].

Cano E., López-González P.J. 2009. Novel mode of postembryonic development in Ammothea genus (Pycnogonida, Ammotheidae) from Antarctic waters // Scientia Marina. Vol.73. No.3. P.541-550.

Cano E., López-González P.J. 2013. New data concerning postembryonic development in Antarctic Ammothea species (Pycnogonida: Ammotheidae) // Polar Biology. Vol.36. No.8. P.1175-1193.

Dunlop J.A. 2005. New ideas about the euchelicerate stem-lineage // Deltshev C., Stoev P. (eds.). European Arachnology. Acta zoologica bulgarica. Suppl. No.1. P.9-23.

Dunlop J.A., Arango C.P. 2005. Pycnogonid affinities: a review // Journal of Zoological Systematics and Evolution Research. Vol.43. No.1. P.8-21.

Ferrari F.D., Fornshell J.A., Vagelli A.A., Ivanenko V.N., Dahms H.-U. 2011. Early post-embryonic development of marine chelicerates and crustaceans with a nauplius // Crustaceana. Vol.84. No.7. P.869-893.

Fornshell J.A, Ferrari F.D. 2012. Larvae of the pycnogonids Ammothea gigantea Gordon, 1932 and Achelia cuneatis Child, 1999 described from archived specimens // Arthropods. Vol.1. No.4. P.121-128.

Gillespie J.M., Bain B.A. 2006. Postembryonic development of Tanystylum bealensis (Pycnogonida, Ammotheidae) from Barkley Sound, British Columbia // Journal of Morphology. Vol.267. P.308-317.

Hodgson T.V. 1907. Pycnogonida // National Antarctic Expedition 1901-1904. Vol.3. P.1-72.

Hoek P.-P.-C. 1881. Nouvelles études sur les Pycnogonides // Archives de zoologie expérimentale et générale. Vol.9. P.445-542.

Morgan T.H. 1891. A contribution to the embryology and phylogeny of the Pycnogonids // Studies from the biological Laboratory of the Johns Hopkins University Vol.5. No.1. P.1-76.

Responsible editor E.V. Bogomolova 